\title{
Carbonyl stretching vibrations of 5-halogen-2-thiophenecarboxaldehydes: KBM, AN, SWAIN and LSER parameters
}

\section{5-halojen-2-tiyofenkarboksaldehitlerin karbonil gerilme titreşimleri: KBM, AN, SWAIN ve LSER parametreleri}

\author{
Cemal PARLAK ${ }^{*}$, Özgür ALVER ${ }^{2}$
}

\author{
1Department of Physics, Science Faculty, Ege University, Izmir, Turkey. \\ cemal.parlak@ege.edu.tr \\ ${ }^{2}$ Department of Physics, Science Faculty, Anadolu University, Eskisehir, Turkey. \\ ozguralver@anadolu.edu.tr
}

\section{Abstract}

Halogen and solvent influence on the conformational stability and carbonyl stretching vibration of 5-Halogeno-2-thiophenecarboxaldehydes $\left(\mathrm{C}_{5} \mathrm{H}_{3} \mathrm{XOS} ; \mathrm{X}=\mathrm{F}, \mathrm{Cl}\right.$ or $\left.\mathrm{Br}\right)$ were investigated by the density functional theory using the B3LYP functional, 6-311+G(3df,p) basis set and polarizable continuum model. Calculations were performed by the cis and trans forms of the compounds in eighteen different solvents. The carbonyl stretching frequencies were correlated with some solvent parameters such as the Kirkwood-Bauer-Magat equation, the solvent acceptor number, Swain parameters and the linear solvation energy relationships. The findings of this research will be useful for thiophenecarboxaldehydes.

Keywords: 5-Halogeno-2-thiophenecarboxaldehyde, DFT, Solvent effect

\section{Introduction}

Polymers of thiophenes have intense interest in literature due to their electrical properties and durability [1]. Thiophenes are well known to exhibit various biological activities such as antiinflammatory agents [2], anti-HIV or some inhibitors [3] and anti-breast cancer [4]. Further, aldehydes are of interest to researchers around the world due to presence of electron-rich, unsaturated $\mathrm{C}=\mathrm{O}$ group, participating in some addition reactions. For $\mathrm{T} 2 \mathrm{C}$, the cis form is defined as having the heaviest (generally nonhydrogen) atom of a substituent group cis to the ring sulfur atom. Experimental and theoretical results for 2TC indicated that the cis form was found to be more stable than the trans [5]-[8].

Organic synthesis is typically carried out in solvents. Molecular properties are strongly solvent dependent. Many interesting reactions take place in the liquid phase. For example, biochemical reactions generally occur in the aqueous environment. Rates of chemical reactions can vary many orders of magnitude depending on the solvent. In this sense, nature and effect of the solute-solvent interaction on the vibrational spectrum are well known [9]-[13]. There are numerous examples of the solvent effect on some group frequencies. The carbonyl has been extensively investigated due to its polarity and hydrogen bond accepting nature [12]-[15]. Furthermore, the empirical approaches such as the Kirkwood-Bauer-Magat (KBM) [16],[17], solvent acceptor number (AN) [18], Swain [19] and linear solvation energy relationships (LSER) [20] have characterized the solvent effect on vibrational frequency.
Öz

5-halojen-2-tiyofenkarboksaldehitlerin (C5H3XOS; $\mathrm{X}=\mathrm{F}, \mathrm{Cl}$ veya $\mathrm{Br}$ ) yapısal denge ve karbonil gerilme titreşimleri üzerindeki çözücü ve halojen etkileri yoğunluk fonksiyoneli teorisi ile B3LYP fonksiyoneli, 6-311+G(3df,p) baz seti ve kutuplanabilir süreklilik modeli kullanılarak incelendi. Hesaplamalar on sekiz farklı çözücü içinde moleküllerin cis ve trans konformasyonları ele alınarak yürütüldü. Cözücü içindek karbonil gerilme titreșim frekansları Kirkwood-Bauer-Magat denklemi, çözücü akseptör sayısl, Swain parametreleri ve lineer çözünme enerji iliş̧isi gibi çözücü skalaları ile incelendi. Bu çalışmanın sonuçları tiyofen-karboksaldehit türevleri için faydalı olacaktır.

Anahtar kelimeler: 5-Halojen-2-tiyofenkarboksaldehit, YFT, Çözücü etkisi

It is clear that the computational description of solvent effects is crucial. The prime objective of the present work was to use density functional theory (DFT) method in conjunction with the B3LYP/6-311+G(3df, p) method to examine the solvent and halogen effects on the conformation and $\mathrm{C}=0$ stretching of the compounds [ $\mathrm{X}=\mathrm{F}$ (5F-2TC), $\mathrm{Cl}$ (5C-2TC) and $\mathrm{Br}$ (5B-2TC)]. Further, the frequencies of carbonyl stretch vibrations were correlated with the KBM, AN, Swain and LSER solvent scales.

\section{Calculations}

Gaussian 09 was used for the calculations [21]. Computations in solutions, without imposing symmetry, were performed by B3LYP/6-311+G(3df,p). The polarizable continuum model. (PCM) was used to evaluate solvent effect. Harmonic vibrational frequencies, scaled by 0.9683 , were calculated by the same level to confirm the nature of the ground state structure. Mole fractions of the individual isomers were computed as described earlier [22]. As described earlier, the $\mathrm{C}=\mathrm{O}$ frequencies were correlated by KBM, AN, Swain and LSER scales to evaluate the solvent effect [9]. KBM, AN, Swain and LSER parameters of the solvents are given in Table 1.

\section{Results and discussion}

Results of the electronic computations on the isomers of the investigated compounds are reported and discussed in detail. Further, solvent effect for the carbonyl stretching of the compounds is also analysed together with several approaches. 


\subsection{Conformational stability}

Mole fractions for the optimized geometries of the two forms of the compounds investigated in solutions are given in Table 2 . There is a linear correlation between the solvent-induced carbonyl frequency and energy values $\left(\mathrm{R}^{2}=0.99951,0.99906\right.$ and 0.99805 for 5F-2TC, 5C-2TC and 5B-2TC, respectively).

In the case of $5 \mathrm{~F}-2 \mathrm{TC}$ in solution, the computed free energies show that the cis form is more stable by $1.64-1.84 \mathrm{kcal} / \mathrm{mol}$. On the basis of the mole fraction computations of individual isomers, 5F-2TC prefers cis and trans forms with approximate probabilities of $94-96 \%$ and $4-6 \%$ correspondingly (Table 2 ).

Moving to the free energies calculated of 5C-2TC and 5B-2TC in solution, similarly, the cis form is more stable than trans by $1.42-1.60$ and $1.41-1.59 \mathrm{kcal} / \mathrm{mol}$. Both $\mathrm{Cl}-$ and $\mathrm{Br}-$-compounds prefer cis and trans forms with approximate probabilities of $92-94 \%$ and $6-8 \%$ correspondingly. The calculated carbonyl bond lengths and dipole moments of the compounds are listed in Table 3.

It was noticed that these $\mathrm{C}=\mathrm{O}$ bond lengths show good and linear correlations with the carbonyl frequencies of the compounds $\left(\mathrm{R}^{2}=0.99940,0.99936\right.$ and 0.99882 for $5 \mathrm{~F}-2 \mathrm{TC}$, $5 \mathrm{C}-2 \mathrm{TC}$ and $5 \mathrm{~B}-2 \mathrm{TC}$ correspondingly). These $\mathrm{C}=\mathrm{O}$ bond lengths increase with the decrease of $v(C=0)$ frequencies.

There are good and linear correlations between the carbonyl frequencies and dipole moments $\left(\mathrm{R}^{2}=0.99960,0.99908\right.$ and 0.99908 , respectively). The dipole moments increase gradually in the solutions. It also increases by the decrease of the $v(C=0)$ frequencies.

\subsection{Carbonyl stretching}

The carbonyl stretching frequencies of the compounds are tabulated in Table 3. For the n-hexane or n-heptane, the carbonyl vibrations are computed at higher frequencies. This belongs to the free monomer state of carbonyl as no remarkable solute-solvent interactions occur in the inert solvent. The $\mathrm{C}=0$ bond lengths increase with the polarity of the solvent. Hence, carbonyl stretching frequencies should decrease. It is clearly observed in Table 3 that this requirement is substantially fulfilled for the compounds.

Table 1: Solvent parameters.

\begin{tabular}{|c|c|c|c|c|c|c|c|c|}
\hline Solvent & $\mathrm{f}(\varepsilon)$ & AN & $\pi^{*}$ & $\delta$ & $\alpha$ & $\beta$ & $\mathrm{A}_{\mathrm{j}}$ & $B_{j}$ \\
\hline n-Hexane & 0.186 & 0.00 & -0.04 & 0.0 & 0.00 & 0.00 & 0.01 & -0.01 \\
\hline n-Heptane & 0.190 & 0.00 & 0.00 & 0.0 & 0.00 & 0.00 & 0.00 & 0.00 \\
\hline Cyclohexane & 0.203 & 1.60 & 0.00 & 0.0 & 0.00 & 0.00 & 0.02 & 0.06 \\
\hline 1.4-dioxane & 0.223 & 10.80 & 0.55 & 0.0 & 0.00 & 0.37 & 0.19 & 0.67 \\
\hline Tetrachloromethane & 0.226 & 8.60 & 0.28 & 0.5 & 0.00 & 0.10 & 0.09 & 0.34 \\
\hline Benzene & 0.231 & 8.20 & 0.59 & 1.0 & 0.00 & 0.10 & 0.15 & 0.59 \\
\hline Toluene & 0.245 & 6.80 & 0.54 & 1.0 & 0.00 & 0.11 & 0.13 & 0.54 \\
\hline Chloroform & 0.359 & 23.10 & 0.58 & 0.5 & 0.20 & 0.10 & 0.42 & 0.73 \\
\hline Tetrahydrofuran & 0.405 & 8.00 & 0.58 & 0.0 & 0.00 & 0.55 & 0.17 & 0.67 \\
\hline Dichloromethane & 0.422 & 20.40 & 0.82 & 0.5 & 0.13 & 0.10 & 0.33 & 0.80 \\
\hline 2-Butanol & 0.454 & 32.00 & 0.40 & 0.0 & 0.69 & 0.80 & - & - \\
\hline 2-Propanol & 0.460 & 33.60 & 0.48 & 0.0 & 0.76 & 0.84 & 0.59 & 0.44 \\
\hline Acetone & 0.465 & 12.50 & 0.62 & 0.0 & 0.08 & 0.48 & 0.25 & 0.81 \\
\hline Ethanol & 0.471 & 37.90 & 0.54 & 0.0 & 0.86 & 0.75 & 0.66 & 0.45 \\
\hline Methanol & 0.478 & 41.50 & 0.60 & 0.0 & 0.98 & 0.66 & 0.75 & 0.50 \\
\hline Dimethylsulfoxide & 0.484 & 19.30 & 0.76 & 0.0 & 1.00 & 0.00 & 0.34 & 1.08 \\
\hline
\end{tabular}

Table 2: Mole fraction of the compounds.

\begin{tabular}{|c|c|c|c|c|c|c|}
\hline \multirow[t]{2}{*}{ Solvent } & \multicolumn{2}{|c|}{$\begin{array}{c}5 \mathrm{~F}-2 \mathrm{TC} \\
\text { Mole fraction (\%) }\end{array}$} & \multicolumn{2}{|c|}{$\begin{array}{c}\text { 5C-2TC } \\
\text { Mole fraction (\%) }\end{array}$} & \multicolumn{2}{|c|}{$\begin{array}{c}\text { 5B-2TC } \\
\text { Mole fraction (\%) }\end{array}$} \\
\hline & Trans & Cis & Trans & Cis & Trans & Cis \\
\hline n-hexane & 5.86 & 94.14 & 8.30 & 91.70 & 8.44 & 91.56 \\
\hline Cyclohexane & 5.82 & 94.18 & 8.25 & 91.75 & 8.30 & 91.70 \\
\hline 1-4-dioxane & 5.77 & 94.23 & 8.23 & 91.77 & 8.18 & 91.82 \\
\hline Tetrachloromethane & 5.76 & 94.24 & 8.26 & 91.74 & 8.20 & 91.80 \\
\hline Toluene & 5.73 & 94.27 & 8.17 & 91.83 & 8.13 & 91.87 \\
\hline Diethylether & 5.33 & 94.67 & 7.71 & 92.29 & 7.31 & 92.69 \\
\hline Chloroform & 5.25 & 94.75 & 7.63 & 92.37 & 7.20 & 92.80 \\
\hline Tetrahydrofuran & 4.96 & 95.04 & 7.20 & 92.80 & 6.84 & 93.16 \\
\hline Dichloromethane & 4.85 & 95.15 & 7.11 & 92.89 & 6.70 & 93.30 \\
\hline 2-butanol & 4.57 & 95.43 & 6.68 & 93.32 & 6.52 & 93.48 \\
\hline 2-propanol & 4.51 & 95.49 & 6.63 & 93.37 & 6.52 & 93.48 \\
\hline Acetone & 4.48 & 95.52 & 6.59 & 93.41 & 6.48 & 93.52 \\
\hline Methanol & 4.36 & 95.64 & 6.41 & 93.59 & 6.46 & 93.54 \\
\hline Acetonitrile & 4.34 & 95.66 & 6.39 & 93.61 & 6.39 & 93.61 \\
\hline Dimethylsulfoxide & 4.29 & 95.71 & 6.32 & 93.68 & 6.43 & 93.57 \\
\hline
\end{tabular}


As can be shown from Tables 3-4, the carbonyl frequencies scaled are inversely proportional to dielectric constant of the solvent. For KBM, there is linear correlation between the carbonyl stretching frequency and $\mathrm{f}(\varepsilon)$. Negative slope means that the frequency is red-shifted by the increase in dielectric constant. Though both the specific and non-specific solvent effects contribute to interactions, KBM only pays regard to the dielectric constant. The results verify that PCM is very successful in determining the effects of solvent on the vibrational frequency. For the AN, however, there are poor correlations and it has no major act in the detection of the frequency shift in solution. Similar results were reported for the KBM and AN equations [9],[23],[24].

Swain divided the solvent effects into two species, the anion (acidity) and cation (basicity) solvating tendency of solvent. Therefore, specific solute-solvent interactions are only kept in view. Correlations of Swain equations are poor like AN (Table 4). Swain considers both Lewis acidity and basicity of solvent whereas Lewis acidity of solvent is only considered in $A N$. The negative signs for $A_{j}$ and $B_{j}$ mean that hydrogen-bond donor (HBD) acidity and hydrogen-bond acceptor (HBA) basicity of the solvent lead to red-shift of carbonyl stretching frequencies. Ratio of these coefficients is equal to about 2 . Red-shift induced by acidity is larger than the one by basicity.

For multiparameter equation LSER, there are not only specific interaction parameters ( $\alpha$ and $\beta$ ), but also non-specific interaction parameter $\left(\pi^{*}\right)$. Similarly, negative $\pi^{*}$ coefficients state that the red-shifts are observed by non-specific solvent effects. The $\pi^{*}$ or $\delta$ coefficients have the biggest absolute values among the others. It supports that the non-specific effects are dominant in the interactions. Further, the $\alpha$ and $\beta$ are negative, in agreement with the Swain coefficients (Table 4). This informs the same influence with regard to the red-shifts by solvent HBD acidity and HBA basicity. The $\alpha$ coefficients are bigger than the $\beta$ values and carbonyl stretching frequencies are more susceptible to HBD acidity than HBA basicity of solvent. The poor correlations of the LSER and Swain, when compared to KBM, verify that the PCM neglects specific solvent effects.

Table 3: Dipole moment ( $\mu$, Debye), carbonyl bond length $(\AA)$ and frequency $\left(v, \mathrm{~cm}^{-1}\right)$ of the compounds.

\begin{tabular}{|c|c|c|c|c|c|c|c|c|c|}
\hline \multirow{2}{*}{ Solvent } & \multicolumn{3}{|c|}{ 5F-2TC } & \multicolumn{3}{|c|}{ 5C-2TC } & \multicolumn{3}{|c|}{ 5B-2TC } \\
\hline & $\mu$ & $\AA ̊$ & $v$ & $\mu$ & $\AA$ & $v$ & $\mu$ & $\AA$ & $v$ \\
\hline n-hexane & 4.09 & 1.2141 & 1675 & 4.07 & 1.2135 & 1676 & 4.07 & 1.2132 & 1677 \\
\hline n-heptane & 4.10 & 1.2142 & 1675 & 4.08 & 1.2135 & 1676 & 4.08 & 1.2133 & 1676 \\
\hline Cyclohexane & 4.13 & 1.2144 & 1673 & 4.11 & 1.2137 & 1675 & 4.12 & 1.2135 & 1675 \\
\hline 1-4-dioxane & 4.19 & 1.2148 & 1671 & 4.17 & 1.2141 & 1672 & 4.18 & 1.2138 & 1673 \\
\hline Tetrachloromethane & 4.20 & 1.2148 & 1671 & 4.18 & 1.2141 & 1672 & 4.18 & 1.2139 & 1673 \\
\hline Benzene & 4.21 & 1.2149 & 1671 & 4.19 & 1.2142 & 1672 & 4.20 & 1.2139 & 1672 \\
\hline Toluene & 4.24 & 1.2151 & 1670 & 4.22 & 1.2143 & 1671 & 4.22 & 1.2141 & 1672 \\
\hline Diethylether & 4.55 & 1.2169 & 1659 & 4.52 & 1.2161 & 1661 & 4.53 & 1.2159 & 1661 \\
\hline Chloroform & 4.59 & 1.2172 & 1657 & 4.57 & 1.2164 & 1659 & 4.58 & 1.2161 & 1660 \\
\hline Tetrahydrofuran & 4.75 & 1.2182 & 1651 & 4.73 & 1.2173 & 1653 & 4.74 & 1.2171 & 1654 \\
\hline Dichloromethane & 4.81 & 1.2185 & 1650 & 4.78 & 1.2176 & 1651 & 4.79 & 1.2174 & 1652 \\
\hline 2-butanol & 4.93 & 1.2192 & 1645 & 4.90 & 1.2183 & 1647 & 4.92 & 1.2181 & 1647 \\
\hline 2-propanol & 4.95 & 1.2194 & 1644 & 4.93 & 1.2185 & 1646 & 4.94 & 1.2182 & 1646 \\
\hline Acetone & 4.96 & 1.2194 & 1644 & 4.94 & 1.2186 & 1645 & 4.95 & 1.2183 & 1646 \\
\hline Ethanol & 4.99 & 1.2196 & 1643 & 4.96 & 1.2187 & 1644 & 4.97 & 1.2184 & 1645 \\
\hline Methanol & 5.01 & 1.2197 & 1642 & 4.99 & 1.2188 & 1644 & 5.00 & 1.2186 & 1644 \\
\hline Acetonitrile & 5.02 & 1.2198 & 1642 & 5.00 & 1.2189 & 1643 & 5.01 & 1.2186 & 1644 \\
\hline Dimethylsulfoxide & 5.04 & 1.2199 & 1641 & 5.01 & 1.2190 & 1643 & 5.03 & 1.2187 & 1643 \\
\hline
\end{tabular}

Table 4: Solvent equations for the carbonyl stretching vibrations.

\begin{tabular}{|c|c|c|c|c|}
\hline Compound & KBM & $\mathrm{R}^{2}$ & AN & $\mathrm{R}^{2}$ \\
\hline $5 \mathrm{~F}-2 \mathrm{TC}$ & $1697.17-114.21 \mathrm{f}(\varepsilon)$ & 0.99796 & 1669.89-0.80 AN & 0.58468 \\
\hline $5 \mathrm{C}-2 \mathrm{TC}$ & $1698.04-112.68 \mathrm{f}(\varepsilon)$ & 0.99719 & 1671.08-0.79 AN & 0.58076 \\
\hline \multirow[t]{2}{*}{$5 \mathrm{~B}-2 \mathrm{TC}$} & $1698.61-112.79 \mathrm{f}(\varepsilon)$ & 0.99642 & $1671.69-0.80 \mathrm{AN}$ & 0.58665 \\
\hline & LSER & & SWAIN & \\
\hline $5 \mathrm{~F}-2 \mathrm{TC}$ & $1674.49-30.40 \pi^{*}+12.68 \delta-10.68 \alpha-9.16 \beta$ & 0.83364 & $1677.07-38.27 \mathrm{~A}_{\mathrm{j}}-17.25 \mathrm{~B}_{\mathrm{j}}$ & 0.73173 \\
\hline $5 \mathrm{C}-2 \mathrm{TC}$ & $1675.85-30.67 \pi^{*}+12.53 \delta-10.15 \alpha-8.98 \beta$ & 0.83371 & $1678.30-37.56 \mathrm{~A}_{j}-17.35 \mathrm{~B}_{\mathrm{j}}$ & 0.73307 \\
\hline $5 \mathrm{~B}-2 \mathrm{TC}$ & $1676.18-29.72 \pi^{*}+12.34 \delta-10.95 \alpha-8.94 \beta$ & 0.83512 & $1678.69-37.98 \mathrm{~A}_{\mathrm{j}}-16.81 \mathrm{~B}_{\mathrm{j}}$ & 0.72974 \\
\hline
\end{tabular}

\section{Conclusions}

We have undertaken a theoretical research, by DFT, to study solvent and halogen effects on the conformational stability and carbonyl stretching of 5-halogeno-2-thiophenecarboxaldehydes. Results will be useful for analysing the conformations involving similar analogous. The important conclusions drawn for the present research are; i. Energy barrier of conformation is independent on the solvent employed for the compounds.

ii. There is no halogen effect on conformations of the compounds.

iii. It is worth to note that the compounds have large dipole moments and this is an essential criterion for drug-receptor interaction [25]. 
iv. Solvent-induced carbonyl frequencies decrease inversely with the dipole moment, bond length and dielectric constant.

v. Swain and LSER parameters have poor correlations whereas KBM shows a good correlation. No linear relationships are observed with AN. Hence, PCM technique reflects non-specific interactions.

\section{References}

[1] Szkurlat A, Palys B, Mieczkowski J, Skompska M. "Electrosynthesis and spectroelectrochemical characterization of poly(3,4-dimethoxy-thiophene), Poly(3,4-dipropyloxythiophene) and poly(3,4dioctyloxythiophene) films". Electrochimica Acta, 48(24), 3665-3676, 2003.

[2] Kumar PR, Raju S, Goud PS, Sailaja M, Sarma RM, Reddy GO, Kumar MP, Reddy VVRM-K, Suresha T, Hegdeb P. "Synthesis and Biological Evaluation of Thiophene [3,2-b] pyrrole derivatives as potential anti-inflammatory agents". Bioorganic \& Medicinal Chemistry, 12(5), 1221-1230, 2004.

[3] Giordanetto F, Karlsson 0, Lindberg J, Larsson LO, Linusson A, Evertsson E, Morgan DGA, Inghardt T. "Discovery of Cyclopentane- and cyclohexane-trans-1,3diamines as potent melanin-concentrating hormone receptor 1 antagonists". Bioorganic \& Medicinal Chemistry Letters, 17(15), 4232-4241, 2007.

[4] Brault L, Migianu E, Neguesque A, Battaglia E, Bagrel D, Kirsch G. "New thiophene analogues of kenpaullone: synthesis and biological evaluation in breast cancer cells". European Journal of Medicinal Chemistry, 40(8), 757-763, 2005.

[5] Kao J, Radom L. "Conformations, stabilities, and charge distributions in 2- and 3-monosubstituted thiophenes. An ab initio molecular orbital study". Journal of the American Chemical Society, 101(2), 311-318, 1979.

[6] Lunazzi L, Placucci G, Chatgilialoglu C, Macciantelli D. "Conformational studies by dynamic nuclear magnetic resonance. part 26. interconversion barriers between syn- and anti-conformers of isomeric thiophenecarbaldehydes". Journal of the Chemical Society, Perkin Transactions, 4, 819-822, 1984.

[7] Braathen GO, Kveseth K, Nielsen CJ, Hagen K. "'Molecular structure and conformational equilibrium of gaseous thiophene-2-aldehyde as studied by electron diffraction and microwave, infrared, raman and matrix isolation spectroscopy". Journal of Molecular Structure, 145(1-2), 45-68, 1986.

[8] Fleming GD, Koch R, Vallete MMC. "Theoretical study of the syn and anti thiophene-2-aldehyde conformers using density functional theory and normal coordinate analysis". Spectrochimica Acta A: Molecular and Biomolecular Spectroscopy, 65(3-4), 935-945, 2006.

[9] Tursun M, Parlak C. "Conformation Stability, Halogen and Solvent Effects on $\mathrm{C}=\mathrm{O}$ Stretching of 4-chloro-3halogenobenzaldehydes". Spectrochimica Acta A: Molecular and Biomolecular Spectroscopy, 141, 58-63, 2015.

[10] Levinson NM, Fried SD, Boxer SG. "Solvent-Induced infrared frequency shifts in aromatic nitriles are quantitatively described by the vibrational stark effect". The Journal of Physical Chemistry B, 116(35), 10470-10476, 2012.
[11] Chen Y, Morisawa Y, Futami Y, Czarnecki MA, Wang HS, Ozaki Y. "Combined IR/NIR and density functional theory calculations analysis of the solvent effects on frequencies and intensities of the fundamental and overtones of the $\mathrm{C}=0$ stretching vibrations of acetone and 2-hexanone". The Journal of Physical Chemistry A, 118(14), 2576-2583, 2014.

[12] Jovic B, Nikolic A, Petrovic S. "FTIR spectroscopic study of hydrogen bonding and solvent induced frequency shifts of N-tert-butylacetamide". Journal of Molecular Structure, 1044, 140-143, 2013.

[13] Ji X, Li Y, Zheng J, Liu Q. "Solvent effects of ethyl methacrylate characterized by FTIR". Materials Chemistry and Physics, 130(3), 1151-1155, 2011.

[14] Vdovenko SI, Gerus II, Kukhar VP. "Solvent effects on the infrared spectra of $\beta$-alkoxyvinyl methyl ketones: I. carbonyl and vinyl stretching vibrations". Spectrochimica Acta A: Molecular and Biomolecular Spectroscopy, 71(3), 779-785, 2008.

[15] Stolov AA, Herrebout WA, Van der Veken BJ. "Solvent effect on vibrational frequencies: cryosolution experiments and density functional calculations". Journal of Molecular Structure, 480-481, 499-503, 1999.

[16] West W, Edwards RT. "The infrared absorption spectrum of hydrogen chloride in solution". The Journal of Chemical Physics, 5, 14-22, 1937.

[17] Bauer E, Magat M. "Deformation of molecules in condensed phases and the hydrogen bond". Journal de Physique et le Radium, 9(8), 319-330, 1938.

[18] Gutmann V, Resch G. The Donor-Acceptor Interactions, New York, USA, Plenum Press, 1978.

[19] Swain CG, Swain MS, Powell AL, Alunni S. "Solvent effects on chemical reactivity. Eevaluation of anion- and cationsolvation components". Journal of the American Chemical Society, 105(3), 502-513, 1983.

[20] Kamlet MJ, Abboud JLM, Abraham MH, Taft RW. "Linear solvation energy relationships. 23. A comprehensive collection of the solvatochromic parameters, .Pi.*, .alpha., and .beta., and Some Methods for simplifying the generalized solvatochromic equation". The Journal of Organic Chemistry, 48(17), 2877-2887, 1983.

[21] Frisch MJ, Trucks GW, Schlegel HB, et al. Gaussian 09, Revision A.1, Gaussian Inc., Wallingford, CT, 2009.

[22] Parlak C. "Theoretical and experimental vibrational spectroscopic study of 4-(1-Pyrrolidinyl) piperidine". Journal of Molecular Structure, 966(1-3), 1-7, 2010.

[23] Sowula M, Misiaszek T, Bartkowiak W. "Solvent effect on the vibrational spectrum of michler's ketone. experimental and theoretical investigations". Spectrochimica Acta A: Molecular and Biomolecular Spectroscopy, 131, 678-685, 2014.

[24] Chen Y, Zhang H, Liu Q. "FT-IR spectroscopy combined with DFT calculation to explore solvent effects of vinyl acetate". Spectrochimica Acta A: Molecular and Biomolecular Spectroscopy, 126, 122-128, 2014.

[25] Parlak C, Kumar CSC, Fun HK, Keşan G, Rhyman L, Ramasami P, Chandraju S, Quah CK. "4-Chloro-3fluorobenzaldehyde: Experimental (XRD, FT-IR and raman) and DFT studies". Journal of Fluorine Chemistry, $163,7-15,2014$. 